\title{
Comparison of Different Multispectral Images to Map Hydrothermal Alteration Zones in Kokap, Kulon Progo
}

\author{
Bayu Raharja*1, Agung Setianto ${ }^{2}$, and Anastasia Dewi Titisari ${ }^{2}$ \\ ${ }^{1}$ Directorate General of Mineral and Coal, Ministry of Energy and Mineral Resources, Jakarta, Indonesia \\ ${ }^{2}$ Department of Geological Engineering, Faculty of Engineering, Universitas Gadjah Mada, Yogyakarta, Indonesia
}

\begin{abstract}
Using remote sensing data for hydrothermal alteration mapping besides saving time and reducing cost leads to increased accuracy. In this study, multispectral remote sensing techniques have been compared for manifesting hydrothermal alteration in Kokap, Kulon Progo. Three multispectral images, including ASTER, Landsat 8, and Sentinel-2, were compared to find the highest overall accuracy using principal component analysis (PCA) and directed component analysis (DPC). Several subsets band combinations were used as PCA and DPC input to targeting the critical mineral of alteration. Multispectral classification with the maximum likelihood algorithm was performed to map the alteration types based on training and testing data, followed by accuracy evaluation. Two alteration zones were succeeded to be mapped: argillic zone and propylitic zone. Results of these image classification techniques were compared with known alteration zones from a previous study. DPC combination of band ratio images of 5:2 and 6:7 of Landsat 8 imagery yielded a classification accuracy of $56.4 \%$, which was $5.05 \%$ and $10.13 \%$ higher than those of the ASTER and Sentinel-2 imagery. The use of DEM and multispectral images increased hydrothermal alteration mapping accuracy in the study area.
\end{abstract}

Keywords: Hydrothermal alteration · ASTER - Landsat 8 - Sentinel-2 - Principle component analysis $\cdot$ Multispectral classification.

\section{INTRODUCTION}

Remote sensing is a typical application of mineral resource mapping activity and usually covers a significant part of various studies focused on spectral analysis, including hydrothermal alteration zone mapping. Rowan et al. (2006) used the visible near-infrared (VNIR) and shortwave infrared (SWIR) wavelength region to detect the mineral assemblages associated with the hydrothermal alteration zone. VNIR bands provide some information about the iron oxides, while SWIR bands measure minerals' reflectance (e.g., clays, phyllosilicates) and are useful for detecting hydrothermal alteration (Gasmi, 2016). Some techniques such

\footnotetext{
*Corresponding author: B. RAHARJA, Directorate General of Mineral and Coal, Ministry of Energy and Mineral Resources, Jakarta, Indonesia.E-mail: bayu.raharja@esdm.go.id
}

as principal component analysis (PCA) and band rationing have been successfully applied by researchers in various locations to map hydrothermal alteration (Tangestani and Moore, 2002; Carranza and Hale, 2002; Crosta et al., 2003).

Kokap region in Kulon Progo is an important region for the presence of gold mineralization. Harjanto (2008) and Pramumijoyo (2017) have proven this gold mineralization is associated with low sulfidation epithermal deposit due to hydrothermal alteration. This alteration can sometimes be detected and mapped at a zonal pattern using remote sensing on a regional scale (Ferrier et al., 2001). The Advanced Spaceborne Thermal Emission and Reflection Radiometer (ASTER), Landsat 8 OLI (Operational and Imager), and Sentinel-2 MSI (MultiSpcetral Instrument) have spectral ranges cov- 
ering the VNIR and SWIR wavelength region. The current study demonstrates the potential and applicability of remote sensing techniques and data for hydrothermal alteration mapping using three different optical sensors: ASTER, Landsat 8, and Sentinel-2. Another aspect of this research study is to perform principle analysis to map hydrothermal alteration zone and find the best band combination based on accuracy.

\section{Geological Setting and Hydrother- MAL Alteration}

The study area is located in the western part of Kulon Progo Regency, Yogyakarta Special Region, with around 80 square kilometers. According to the Regional Geological Map number 1408-2 and 1407-5 from the Geological Agency of Republic Indonesia (Figure 1), the study area is located in the Oligo-Miocene andesite intrusion (a). This intrusion breaks through Nanggulan Formation (Teon) and Kebobutak Formation (Tmok) (Rahardjo et al., 1995). In addition, some geological structures are identified due to volcanism and secondary processes (Widagdo et al., 2016). The hydrothermal fluid that is carrying mineralization is then circulated through this geological structure. These may be faults, joints, cracks or fissures, or simply boundaries of grains (Pramumijoyo, 2017).

According to Harjanto (2008), Sulthoni (2017), and Pramumijoyo (2017), there are three groups of hydrothermal alteration zone found in this study area: silicification, argillic, and propylitic and is characterized by the different mineral assembly. The Silicification zone (highly altered) located in the center of alteration is typically characterized by secondary minerals of quartz and illite. Argillic zone (medium altered) is typically characterized by illite, montmorillonite, and kaolinite. Propylitic alteration, the outermost zone formed in the lower temperature, typically contains chlorite and epidote as the altered secondary mineral.

\section{Methodology}

The methodology involves image processing, field observations and laboratory analysis (thin section and X-ray diffraction analysis), multispectral classification, and accuracy evaluation.

\subsection{Data preprocessing}

Three types of multispectral imagery were downloaded from the earth explorer website and used in this study, ASTER image recorded on September 9, 2003, Landsat 8 image (path 120 row 65) recorded on September 18, 2015, and Sentinel-2 image recorded on July 28, 2018. These images (ASTER, Landsat 8 , and Sentinel2) have different spatial and spectral resolutions (Table 1). In addition, one scene of SRTM (Shuttle Radar Topography Mission) DEM (digital elevation model) with $12,5 \mathrm{~m}$ spatial resolution was downloaded from the Alaska Satellite Facility (ASF) website. These scenes were georeferenced in the UTM zone 49S coordinate system with the WGS-84 ellipsoid.

Image pre-processing such as radiometric calibration (including atmospheric correction) and masking were applied to the images. Atmospheric corrections are used to eliminate the influence of elements and molecules in the atmosphere, so radians or reflections values are close to their original values (Surface Reflectance) (Vermote et al., 2002; Wicaksono and Danoedoro, 2012). The ASTER and Landsat 8 images were corrected using the FLAASH (Fast Line-of-sight Atmospheric Analysis of $\mathrm{Hy}-$ percubes) module. In contrast, the Sentinel-2 images are atmospherically corrected orthorectified using the Sentinel Application Platform (SNAP) software package. Masking processes are then performed to crop the images only at the research study area and eliminate other objects such as the sea and clouds since they interfere with the PC processes (Table 2).

\subsection{Hydrothermal alteration identification using remote sensing}

The visible and shortwave bands are considered bands that can distinguish the type of mineral from its spectral reflection characteristics or spectral signature (Abrams et al., 1977, Taranik and Crosta, 1996; Carranza, 2002). To identify the mineral assembly of hydrothermal alteration, PCA was applied to subsets of multispectral images. PCA (also known as the Crósta method) transforms spectral values on images to reduce data redundancy. Band selection as PC input was based on the spectral response of multispectral bands to each target mineral (Table 3). The results of PCs that are contain- 


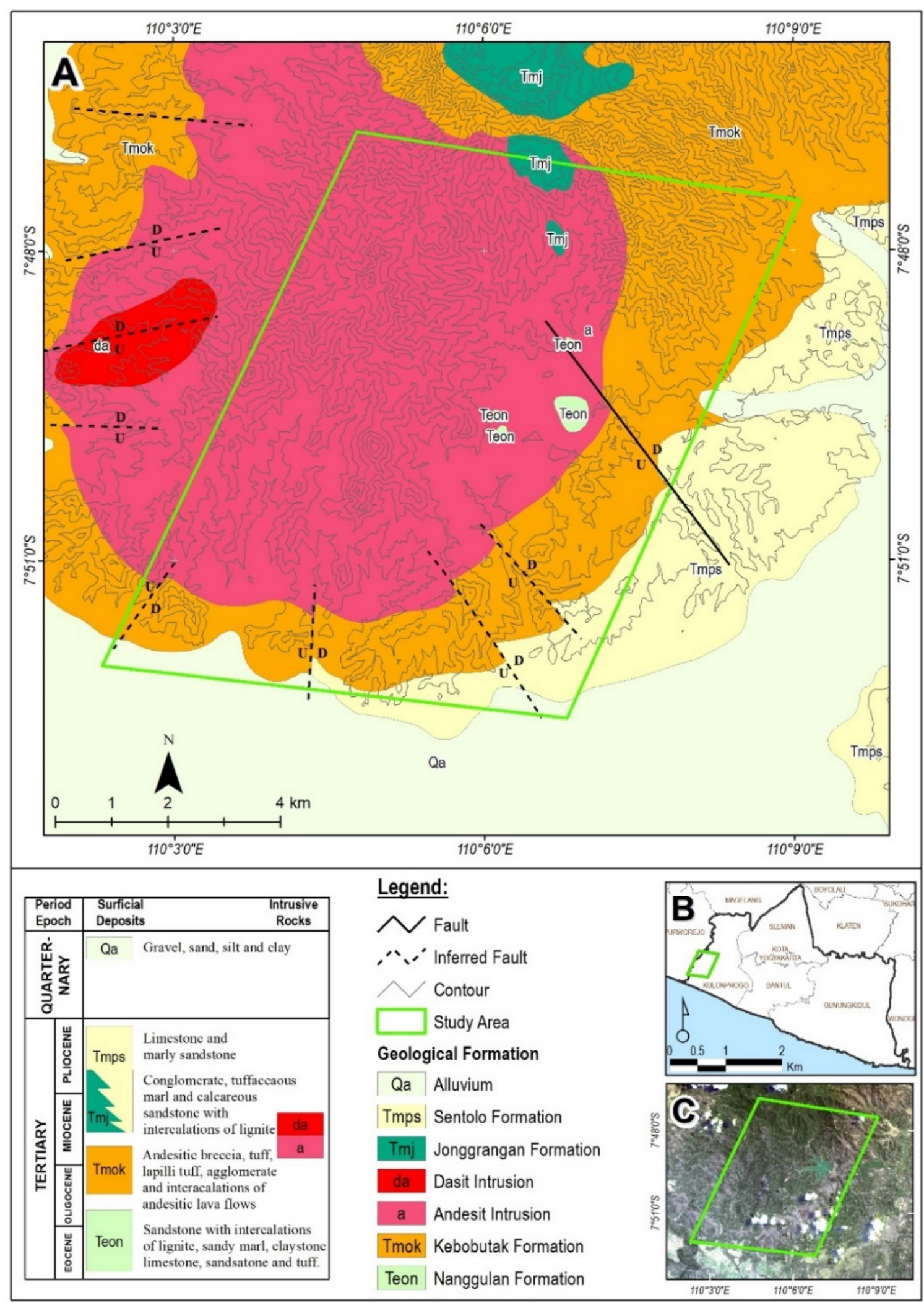

FIGURE 1. Geological map of Kokap and surrounding modified from Regional Geological Map created by Geological Agency of Republic Indonesia (A). Index map of Yogyakarta Special Region. Study area marked with the polygon in light green color (B). Landsat 8 true-color composite image (RGB: bands 4-3-2) (C) (Rahardjo et al., 1995). 
TABLE 1. ASTER, Landsat 8, and Sentinel-2 detail sensor .

\begin{tabular}{|c|c|c|c|c|c|c|c|c|}
\hline \multicolumn{3}{|c|}{ ASTER } & \multicolumn{3}{|c|}{ OLI } & \multicolumn{3}{|c|}{ Sentinel-2 } \\
\hline Band & $\begin{array}{l}\text { Central } \\
\text { Wave- } \\
\text { length } \\
(\mathrm{nm})\end{array}$ & $\begin{array}{l}\text { Spatial } \\
\text { Resolution } \\
(\mathrm{m})\end{array}$ & Band & $\begin{array}{c}\text { Central } \\
\text { Wave- } \\
\text { length } \\
(\mathrm{nm})\end{array}$ & $\begin{array}{l}\text { Spatial } \\
\text { Resolution } \\
(\mathrm{m})\end{array}$ & Band & $\begin{array}{c}\text { Central } \\
\text { Wave- } \\
\text { length } \\
(\mathrm{nm})\end{array}$ & $\begin{array}{c}\text { Spatial } \\
\text { Resolution } \\
(\mathrm{m})\end{array}$ \\
\hline 1 & 0.5560 & \multirow{4}{*}{15} & 1 & 0.4430 & \multirow{7}{*}{30} & 1 & 0.4430 & 60 \\
\hline 2 & 0.6610 & & 2 & 0.4826 & & 2 & 0.4900 & \multirow{3}{*}{10} \\
\hline $3 \mathrm{~N}$ & 0.8070 & & 3 & 0.5613 & & 3 & 0.5600 & \\
\hline $3 B$ & 0.8070 & & 4 & 0.6546 & & 4 & 0.6650 & \\
\hline 4 & 1.6560 & \multirow{6}{*}{30} & 5 & 0.8646 & & 5 & 0.7050 & \multirow{3}{*}{20} \\
\hline 5 & 2.1670 & & 6 & 1.6090 & & 6 & 0.7400 & \\
\hline 6 & 2.2090 & & 7 & 2.2010 & & 7 & 0.7830 & \\
\hline 7 & 2.2620 & & \multirow[t]{2}{*}{8} & 0.5917 & 15 & 8 & 0.8420 & 10 \\
\hline 8 & 2.3360 & & & & & $8 \mathrm{~A}$ & 0.8650 & \multirow{3}{*}{$\begin{array}{l}20 \\
60\end{array}$} \\
\hline 9 & 2.4000 & & 9 & 1.3730 & 30 & 9 & 0.9450 & \\
\hline 10 & 8.2910 & \multirow{5}{*}{90} & 10 & 10.9000 & & 10 & 1.3750 & \\
\hline 11 & 8.6340 & & & & 100 & 11 & 1.6100 & \multirow{4}{*}{20} \\
\hline 12 & 9.0750 & & & & & & & \\
\hline 13 & 10.6570 & & 11 & 12.0000 & & 12 & 2.1900 & \\
\hline 14 & 11.3180 & & & & & & & \\
\hline
\end{tabular}

TABLE 2. Images statistic after masking (the digital number is in reflectance).

\begin{tabular}{|c|c|c|c|c|c|}
\hline & Band & Min & Max & Mean & Stdev \\
\hline \multirow{9}{*}{$\begin{array}{l}\frac{\sqrt{u}}{\mid c} \\
\frac{\sqrt{2}}{4}\end{array}$} & Band 1 & 0.0 & 0.382 & 0.032 & 0.029 \\
\hline & Band 2 & 0.0 & 0.421 & 0.056 & 0.05 \\
\hline & Band 3 & 0.0 & 0.465 & 0.14 & 0.117 \\
\hline & Band 4 & 0.0 & 0.437 & 0.12 & 0.102 \\
\hline & Band 5 & 0.0 & 0.253 & 0.046 & 0.042 \\
\hline & Band 6 & 0.0 & 0.29 & 0.05 & 0.046 \\
\hline & Band 7 & 0.0 & 0.27 & 0.046 & 0.042 \\
\hline & Band 8 & 0.0 & 0.224 & 0.031 & 0.03 \\
\hline & Band 9 & 0.0 & 0.142 & 0.014 & 0.016 \\
\hline \multirow{7}{*}{ 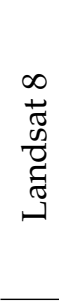 } & Band 1 & 0.0 & 0.559 & 0.027 & 0.036 \\
\hline & Band 2 & 0.0 & 0.593 & 0.029 & 0.037 \\
\hline & Band 3 & 0.0 & 0.65 & 0.042 & 0.045 \\
\hline & Band 4 & 0.0 & 0.693 & 0.038 & 0.045 \\
\hline & Band 5 & 0.0 & 0.81 & 0.163 & 0.139 \\
\hline & Band 6 & 0.0 & 0.782 & 0.109 & 0.099 \\
\hline & Band 7 & 0.0 & 0.628 & 0.058 & 0.059 \\
\hline \multirow{7}{*}{$\begin{array}{l}\frac{T}{\Phi} \\
. \Xi \\
\mathscr{D} \\
\tilde{D}\end{array}$} & Band & 0.0 & 0.207 & 0.026 & 0.021 \\
\hline & Band 2 & 0.0 & 0.466 & 0.025 & 0.021 \\
\hline & Band 3 & 0.0 & 0.462 & 0.028 & 0.025 \\
\hline & Band 4 & 0.0 & 0.567 & 0.034 & 0.031 \\
\hline & Band 8 & 0.0 & 0.566 & 0.141 & 0.121 \\
\hline & Band 11 & 0.0 & 0.002 & 0.001 & 0.001 \\
\hline & Band 12 & 0.0 & 0.399 & 0.09 & 0.079 \\
\hline
\end{tabular}

ing targeted minerals will have a high eigenvector loading value. Fraser and Green (1987) and Loughlin (1991) used a combination of twoband ratio images as PCA input (also known as direct principle component or DPC method) to increase the spectral detection capabilities. When only two bands are used as input to PC processes, the spectral contrast is mapped into the second component. By limiting the number of PC inputs, the result will be easier for visual interpretation.

\subsection{Multispectral classification}

PC images generated from multispectral are classified into hydrothermal alteration zones by maximum likelihood classification, a standard supervised classifier method in remote sensing. This method assumes that each object on the earth's surface has different spectral reflectance to be grouped based on its spectral value. Maximum Likelihood is one of the techniques used in estimating a data distribution parameter and remains dominantly used in developing new tests (Lehmann and Casella, 1998). To execute maximum likelihood classification, training and testing samples were needed based on the observation data. This observation data (Figure 2) is divided into two sets of pixels used 
TABLE 3. Selected bands combination for PC input.

\begin{tabular}{llccc}
\hline Method & Target & ASTER & Landsat 8 & Sentinel-2 \\
\hline \multirow{5}{*}{ PCA } & Montmorillonite & $1-3-5-7$ & $3-5-7 \dagger$ & $3-8-12 \dagger$ \\
& Illite & $1-3-5-6$ & $3-5-7 \dagger$ & $3-8-12 \dagger$ \\
& Kaolinite + smectite & $1-4-6-9$ & $3-6-7 \dagger$ & $3-11-12 \dagger$ \\
& Kaolinite & $1-4-6-7$ & $3-6-7 \dagger$ & $3-11-12 \dagger$ \\
& Limonitic alteration & $1-3-4-7$ & $2-4-5-6$ & $2-4-8-11$ \\
& Clay alteration & $1-3-4-5$ & $2-5-6-7$ & $2-8-11-12$ \\
\hline \multirow{6}{*}{ DPC } & Limonitic alteration & $2 / 1 ; 3 / 1$ & $4 / 2 ; 5 / 4$ & $4 / 2 ; 8 / 4$ \\
& Clay Alteration & $3 / 2 ; 4 / 6$ & $5 / 4 ; 6 / 7$ & $8 / 4 ; 11 / 12$ \\
& Quartz & $1 / 2 ; 6 / 2$ & $3 / 4 ; 7 / 2$ & $3 / 4 ; 12 / 2$ \\
& Montmorillonite & $1 / 2 ; 4 / 1$ & $3 / 4 ; 6 / 2$ & $3 / 4 ; 11 / 2$ \\
& Illite & $3 / 1 ; 6 / 1$ & $5 / 3 ; 7 / 2$ & $8 / 3 ; 12 / 2$ \\
& Chlorite & $3 / 1 ; 4 / 1$ & $5 / 3 ; 6 / 2$ & $8 / 3 ; 11 / 2$ \\
& Epidote & $3 / 1 ; 4 / 6$ & $5 / 2 ; 6 / 7$ & $8 / 2 ; 11 / 12$ \\
& Limonitic alteration & $2 / 1 ; 3 / 1$ & $4 / 2 ; 5 / 4$ & $4 / 2 ; 8 / 4$ \\
\hline
\end{tabular}

$\dagger$ ASTER band 5-7 fall within band 7 of Landsat 8 and band 12 of Sentinel-2

for supervised classification: (a) training pixels (classification sample) and (b) testing pixels (reference sample).

\subsection{Accuracy evaluation}

The classification performance was quantitatively assessed by computing the overall accuracy, Kappa coefficient, and Z-statistic. The overall accuracy is the ratio between the total number of correct pixels and the total number of pixels in the error matrix. The Kappa coefficient is a statistical measure that represents the accord between classified maps and reference data. Z-statistic is used to measure the level of significance of the classification (Congalton and Green, 1999).

\section{RESUlts AND Discussion}

\subsection{Data samples}

The selected field observation sites obtained from each set were collected and subjected to thin sections observations and analysis under a microscope (Figure $3 \mathrm{~A}$ ) and $\mathrm{X}$-ray diffraction (XRD) analysis (Figure 3B-C). Some minerals such as quartz, kaolinite, illite, and montmorillonite were present (Table 4). In total, 133 samples were selected from observation, and secondary data collection (Harjanto, 2008; Pramumijoyo, 2017; and Sulthoni, 2017), then divided into 65 classification samples and 68 testing samples. Training and testing pixels also contain information for a water body and unaltered areas.
TABLE 4. Rock samples representing altered minerals.

\begin{tabular}{|c|c|c|c|}
\hline Analysis & $\begin{array}{l}\text { Sample } \\
\text { Number }\end{array}$ & $\begin{array}{l}\text { Altered } \\
\text { Mineral }\end{array}$ & Alteration \\
\hline \multirow{5}{*}{ XRD } & 008 & Quartz, Illite & Silicification \\
\hline & 011 & Quartz & Silicification \\
\hline & 015 & Quartz & Silicification \\
\hline & 020 & $\begin{array}{l}\text { Montmoril- } \\
\text { lonite }\end{array}$ & Argillic \\
\hline & 039 & $\begin{array}{l}\text { Kaolinite, } \\
\text { Montmoril- } \\
\text { lonite }\end{array}$ & Argillic \\
\hline \multirow{6}{*}{$\begin{array}{l}\text { Thin } \\
\text { Section }\end{array}$} & 006 & $\begin{array}{l}\text { Chlorite, } \\
\text { Carbonate }\end{array}$ & Propylitic \\
\hline & 012 & $\begin{array}{l}\text { Chlorite, } \\
\text { Carbonate }\end{array}$ & Propylitic \\
\hline & 021 & $\begin{array}{l}\text { Chlorite, } \\
\text { Carbonate }\end{array}$ & Propylitic \\
\hline & 025 & $\begin{array}{l}\text { Chlorite, } \\
\text { Carbonate }\end{array}$ & Propylitic \\
\hline & 038 & Chlorite & Propylitic \\
\hline & 041 & Chlorite & Propylitic \\
\hline
\end{tabular}

\subsection{Targeting hydrothermal alteration miner- als}

PCA and DPC methods were used to identify the critical mineral of hydrothermal alteration based on subsets bands mentioned in Table 3 . The result of applying PCA and DPC is the eigenvector loading. The selection of PCs image that containing the target minerals shows the highest eigenvector loadings. If the loading of the reflective band is positive in sign, the tar- 


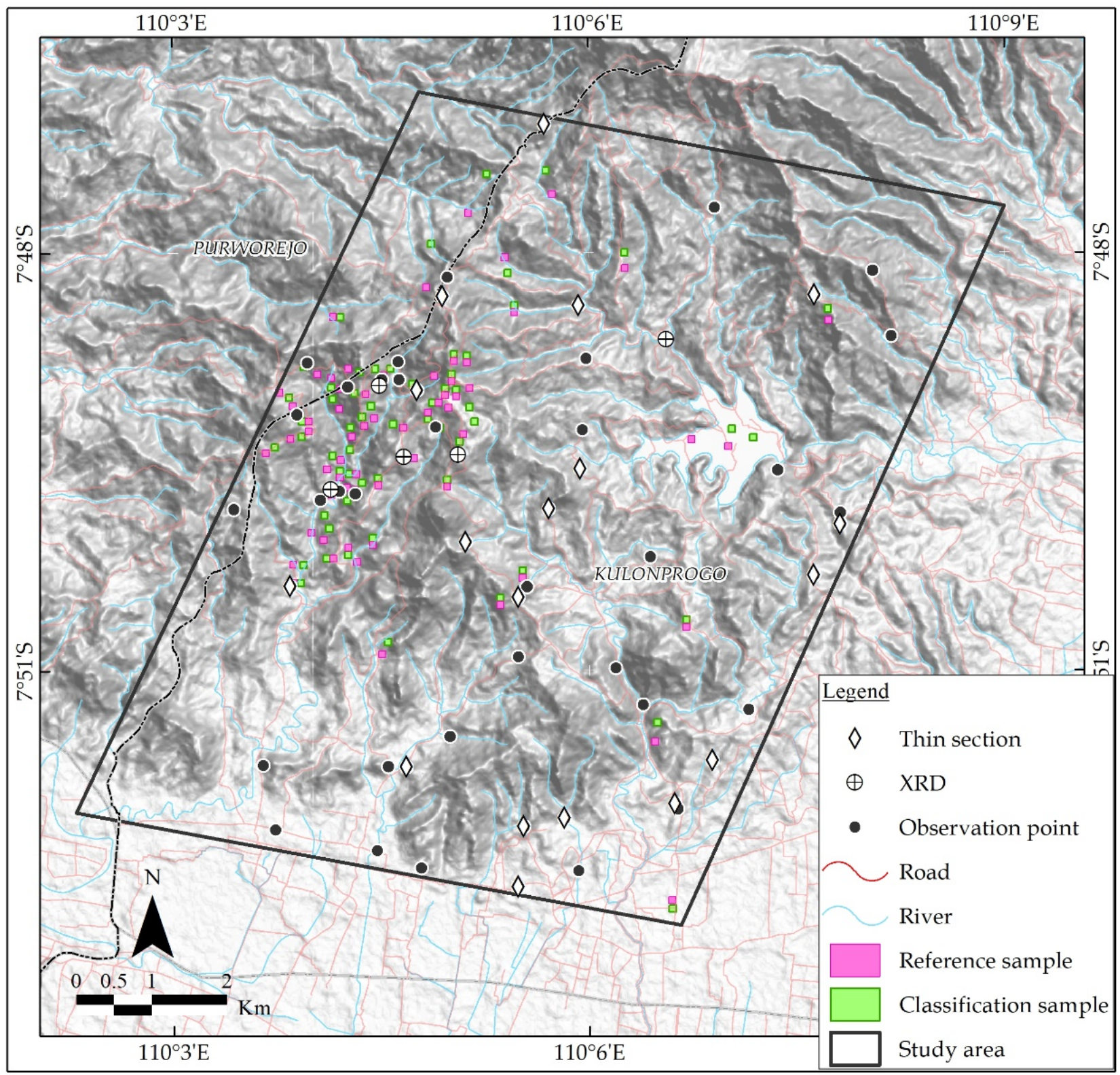

FIGURE 2. Distribution of thin section location (diamond), XRD locations (circle), observation point (black dot), training pixels (green square), and testing pixels (pink square) in the study area. Training and testing samples were collected from primary and secondary data (Harjanto, 2008; Pramumijoyo, 2017; and Sulthoni, 2017). 

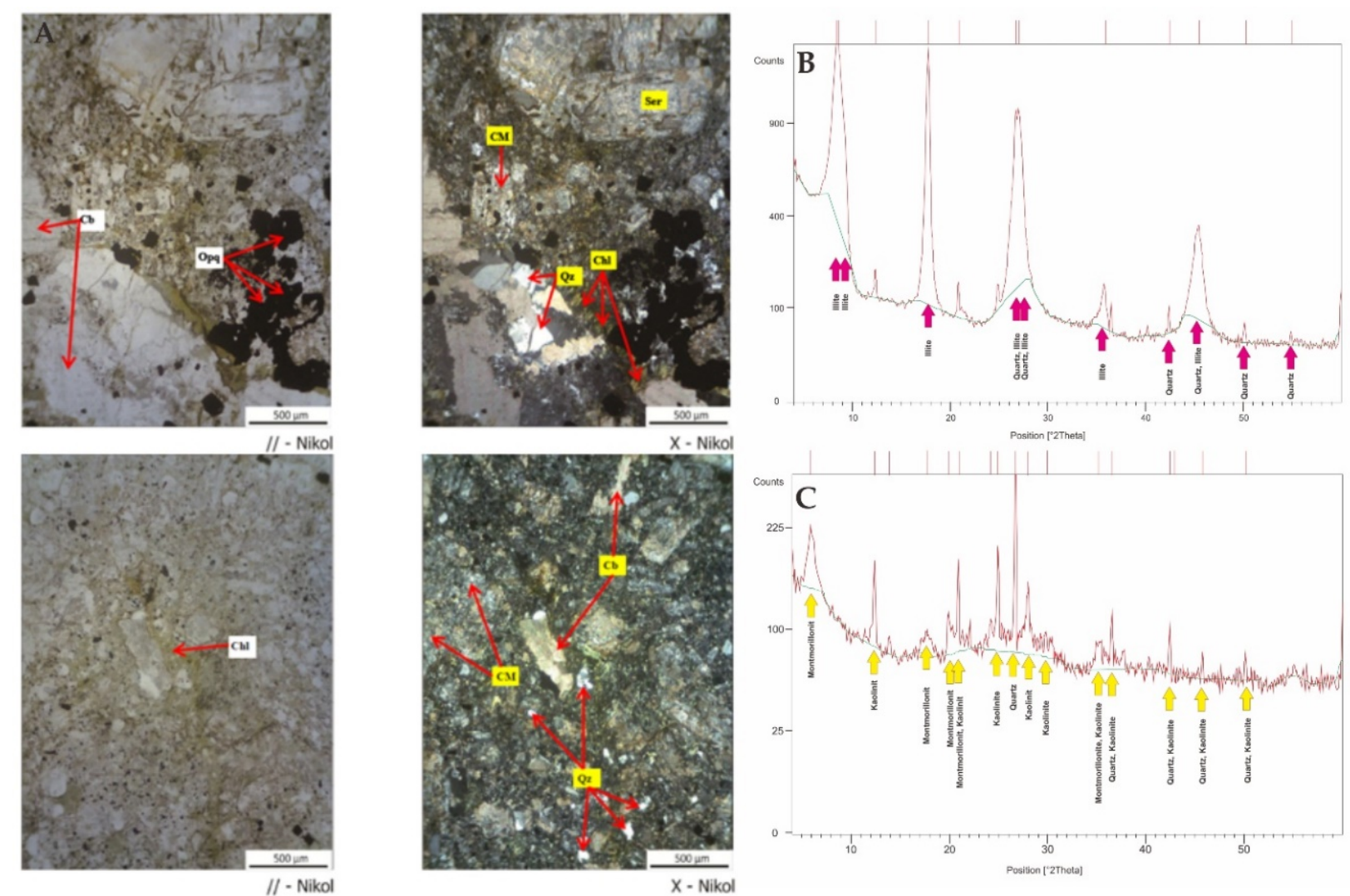

FIGURE 3. Thin-section analysis from sample 012 showed an altered rock. It is originally an igneous rock with a porphyritic texture. Minerals consist of carbonate/ $\mathrm{Cb}(40 \%)$, secondary quartz/Qz $(10 \%)$, clay minerals/Cm (15\%), chlorite/Chl (30\%) and opaque minerals/Opx (5\%) and indicated as propylitic alteration (A). Some alteration minerals detected from samples 008 (B) and 039 (C) by XRD analysis contain quartz, illite, kaolinite, and montmorillonite. This location is experienced silicification (sample 008) and argillic (sample 039) alteration. 
get area is shown by bright pixels; if the loading of the reflective band is negative, the area is shown by dark pixels (Crosta and Moore, 1989).

\subsubsection{Result of ASTER image}

Several combinations of PCA inputs were used to map the distribution of alteration minerals. The PCA combination of bands 1-4-6-7 is used to map kaolinite. Illite has high reflectance values in ASTER bands of 1,3 , and 5 and low reflectance in ASTER bands 6. Hence, PCA combinations of ASTER bands 1-3-5-6 are used to map illite minerals. PCs 1-3-5-7 are used to map montmorillonite minerals. Montmorillonite has high spectral responses in band 3 and band 7 and low spectral responses in band 1 and band 5. Clay alteration is mapped using a combination of PC bands 1-3-4-7.

Furthermore, limonitic alteration is mapped using a combination of PC bands 1-3-4-5. Limonite has a high spectral response in bands 4 and 5 and a low spectral response in bands 1 and 3. Several DPC combinations are used to map quartz, montmorillonite, illite, chlorite, and epidote. The DPCs result showed that DPC1 for quartz, montmorillonite, illite, chlorite, and epidote are all harmful, hence zones where the spectral responses due to vegetation and altered minerals cannot be differentiated. DPC2 accounts for the contrast between zones that contain altered minerals from those that contain vegetation. The selected and used PCs band to map the distribution of alteration minerals are indicated by "bold" text in Table 5 and Table 6.

\subsubsection{Result of Landsat 8 image}

The combination of Landsat 8 band 3-6-7 was used to identify the abundance of kaolinite and montmorillonite. Both minerals have a high spectral response on band 3 and band 6 and have low reflectance on band 7 . Combinations of Landsat 8 band 3-5-7 are used to map illite. Illite has a high spectral response in Landsat 8 band 3 and band 5 and has a low response on band 7 . To targeting clay alteration, a combination of band 2-5-6-7 is used as an input to the PC. Limonitic alteration is mapped using Landsat 8 bands 2-4-5-6 that are sensitive to map ferric ion elements.

Some DPC images were used to map the distribution of the secondary altered minerals. Quartz is mapped using band ratio images band 7:2. DPC analysis with band ratio images $6: 2$ is used to mapped montmorillonite. Illite has a high spectral response on band 7 and a low spectral response on band 2, the combination of ratio images 7: 2 is chosen. Chlorite is best mapped with band ratio image $6: 2$ because they have a high spectral response on band 6 and a low spectral response on band 2. To separate vegetation from chlorite, a combination of band ratio image 5:3 is selected. Thus, chlorite is mapped with band ratio images of $6: 2$ and 5:3. Epidote is mapped using a combination of band ratio image 6:7. Target minerals in the selected PCA and DPC are characterized by eigenvector loadings in "bold" (Table 7 and Table 8).

\subsubsection{Result of Sentinel-2 image}

Sentinel-2 images have spectral similarity with the Landsat- 8 images, so we need to adjust PC combinations of Landsat 8 to the Sentinel2 band wavelength. Kaolinite and montmorillonite are mapped using a PC band 3-11-12. The PC combination of band 3-8-12 is used to map illite minerals. Clay alteration is mapped using combinations of Sentinel-2 band 2-8-1112 , while limonitic alteration is mapped using a combination of Sentinel-2 band 2-4-8-11. Image transformation using the DPC method was performed to map the abundance of secondary altered minerals. The first band ratio image should highlight the target mineral, and the second band ratio should contain information about another object interfering with the target mineral. The first band ratio contains mapped mineral information, while the second band ratio accommodates vegetation response. The results show that all DPC calculations have strong similarities based on loadings value (both negative value) in DPC1 so that vegetation and target minerals cannot be differentiated. DPC2 has opposite loadings value sign (positive and negative); thus, map zones containing target minerals (characterized by eigenvector loadings in bold in Table 9 and Table 10). 
TABLE 5. Eigenvector loadings for ASTER PCA combination.

\begin{tabular}{lccccl}
\hline & PC1 & PC2 & PC3 & PC4 & Alteration Minerals \\
\hline Band 1 & 0.37 & -0.12 & 0.92 & 0.10 & \\
Band 4 & 0.78 & $\mathbf{0 . 5 8}$ & -0.24 & 0.01 & \\
Band 6 & 0.37 & $\mathbf{- 0 . 5 7}$ & -0.21 & -0.70 & Kaolinite \\
Band 7 & 0.35 & -0.57 & -0.22 & 0.71 & \\
Eigen values (\%) & 93.6 & \multicolumn{1}{l}{ 3.37 } & 2.5 & 0.53 & \\
\hline Band 1 & -0.34 & -0.20 & $\mathbf{0 . 9 2}$ & 0.004 & \\
Band 3 & -0.84 & $\mathbf{0 . 5 1}$ & -0.20 & -0.003 & \\
Band 5 & -0.29 & -0.57 & -0.23 & -0.73 & Illite \\
Band 6 & -0.32 & -0.61 & $\mathbf{- 0 . 2 5}$ & 0.68 & \\
Eigen values (\%) & 91.85 & 6.12 & $\mathbf{1 . 5 8}$ & 0.45 & \\
\hline Band 1 & 0.5 & 0.35 & $\mathbf{- 0 . 7 9}$ & -0.001 & \\
Band 3 & 0.49 & 0.64 & $\mathbf{0 . 5 9}$ & 0.02 & \\
Band 5 & 0.51 & -0.47 & 0.12 & -0.71 & Montmorillonite \\
Band 7 & 0.5 & -0.49 & 0.10 & 0.7 & \\
Eigen values (\%) & 89.24 & 7.12 & $\mathbf{2 . 5 5}$ & 1.09 & \\
\hline Band 1 & 0.51 & 0.24 & 0.78 & -0.29 & \\
Band 3 & 0.49 & $\mathbf{0 . 6 4}$ & -0.34 & 0.49 & \\
Band 4 & 0.51 & -0.17 & -0.53 & $\mathbf{- 0 . 6 6}$ & Clay alteration \\
Band 7 & 0.49 & $\mathbf{- 0 . 7 1}$ & 0.08 & $\mathbf{0 . 4 9}$ & \\
Eigen values (\%) & 91.91 & 4.77 & 1.75 & $\mathbf{1 . 5 7}$ & \\
\hline Band 1 & 0.51 & 0.24 & 0.76 & -0.33 & \\
Band 3 & 0.49 & $\mathbf{0 . 6 4}$ & -0.31 & 0.5 & Limonitic alteration \\
Band 4 & 0.51 & -0.17 & -0.56 & -0.63 & \\
Band 5 & 0.49 & $\mathbf{- 0 . 7 1}$ & 0.11 & 0.49 & \\
Eigen values (\%) & 92.02 & $\mathbf{4 . 6 2}$ & 1.75 & 1.61 & \\
\hline & & & & & \\
\hline
\end{tabular}


TABLE 6. Eigenvector loadings for ASTER DPC combination.

\begin{tabular}{lrrl}
\hline & DPC1 & DPC2 & $\begin{array}{l}\text { Alteration } \\
\text { Minerals }\end{array}$ \\
\hline Band 1 : Band 2 & -0.69 & $\mathbf{- 0 . 7 2}$ & \\
Band 6 : Band 2 & -0.72 & $\mathbf{0 . 6 9}$ & Quartz \\
Eigen values (\%) & 94.24 & $\mathbf{5 . 7 6}$ & \\
\hline Band 1 : Band 2 & -0.45 & $\mathbf{- 0 . 8 9}$ & Montmoril- \\
Band 4 : Band 1 & -0.89 & $\mathbf{0 . 4 5}$ & lonite \\
Eigen values (\%) & 97.46 & $\mathbf{2 . 5 4}$ & \\
\hline Band 3 : Band 1 & 0.94 & $\mathbf{- 0 . 3 3}$ & \\
Band 6 : Band 1 & 0.33 & $\mathbf{0 . 9 4}$ & Illite \\
Eigen values (\%) & 96.05 & $\mathbf{3 . 9 5}$ & \\
\hline Band 3 : Band 1 & -0.33 & $\mathbf{- 0 . 9 4}$ & \\
Band 4 : Band 1 & -0.94 & $\mathbf{0 . 3 3}$ & Chlorite \\
Eigen values (\%) & 96.05 & $\mathbf{3 . 9 5}$ & \\
\hline Band 3 : Band 1 & -0.49 & $\mathbf{- 0 . 8 7}$ & \\
Band 4 : Band 6 & -0.87 & $\mathbf{0 . 4 9}$ & Epidote \\
Eigen values (\%) & 83.25 & $\mathbf{1 6 . 7 5}$ & \\
\hline
\end{tabular}

\subsection{Multispectral classification and accuracy assessment}

The maximum likelihood classification is performed to map the hydrothermal alteration zone based on PC images and sample data. Alteration zones are identified as silicification, argillic, and propylitic based on the mineral assemblies. Although three types of alteration zones have been identified, only two can be mapped in this study because of image spatial resolution limitations. These units are, respectively, the argillic and propylitic zones. Carranza (2002) studied that the application of DEM can improve the multispectral classification result. SRTM is then used together with PC images to improve the classification of hydrothermal alteration zones. DEM values which lay from $32 \mathrm{~m}$ to $622 \mathrm{~m}$, were stretched to 0-1 scale, similar to multispectral images range.

The best multispectral classification for hydrothermal alteration of ASTER image was given by the PCA 1-4-6-7 with an overall accuracy of $50.28 \%$ and kappa coefficient of 0.26 (indicated in "bold" in Table 11). The DEM inclusion in multispectral classification increased the overall accuracy to $54.45 \%$ and the kappa coefficient to 0.32 . Z-statistic value before and after DEM includes the critical value of 2.58 at the $99 \%$ confidence level, which implies that this classification is better than a random clas- sification. The pairwise comparison is used to compares the error matrices, two at a time, to determine if they are significantly different. It is showed that these two matrices, before and after the inclusive of DEM, are significantly different. Notice that the pairwise comparison value from eight out of ten PC combinations exceeds the critical value at $95 \%$ confidence level (the critical value would be 1.96), characterized in italic bold in Table 11. The final hydrothermal alteration map from ASTER before DEM and after DEM is displayed in Figure 4A-B.

The highest multispectral classification accuracy of the Landsat 8 image was shown by combining band ratios of 5:2 and 6:7 with an overall accuracy of $56.64 \%$, kappa coefficient of 0.36 , and Z-statistic value of 17.93 (indicated in "bold" in Table 11). Z-statistic value (17.93) exceeds the critical value at a $99 \%$ confidence level, implying that this classification is better than random classification. The combination of DEM and multispectral images were succeeded increase the overall accuracy to $59.5 \%$, with a kappa coefficient of 0.4 and Z-statistic value of 20.35 (indicated in "bold" in Table 11). Zvalues for the pairwise comparison test showed that these two matrices (before and after DEM) are not significantly different, characterized in italic bold in Table 11. The pairwise calculation shows that only two out of ten PC combinations exceed the critical value at a $95 \%$ confidence level. Figure $4 \mathrm{C}-\mathrm{D}$ is the final hydrothermal alteration zone generated from Landsat 8 DPC images of band 5:2 and band 6:7 exclusive and inclusive of DEM.

The best result of Sentinel-2 multispectral classification for hydrothermal alteration was given by combining band rations of $8: 3$ and 11:2 with an overall accuracy of $46.61 \%$ and a kappa coefficient of 0.21. DEM was succeeded increase the overall accuracy to $49.37 \%$ with a kappa coefficient of 0.25 . Z-statistic value before (26.72) and after (32.04) the inclusive of DEM exceeds the critical value at the $99 \%$ confidence level, which implies that this classification is better than a random classification. The pairwise comparison test showed that eight out of ten combinations exceed the critical value at $95 \%$ confidence level, indicate that the matric before and after DEM are significantly different (marked as italic bold in Table 11). Comparison of classi- 

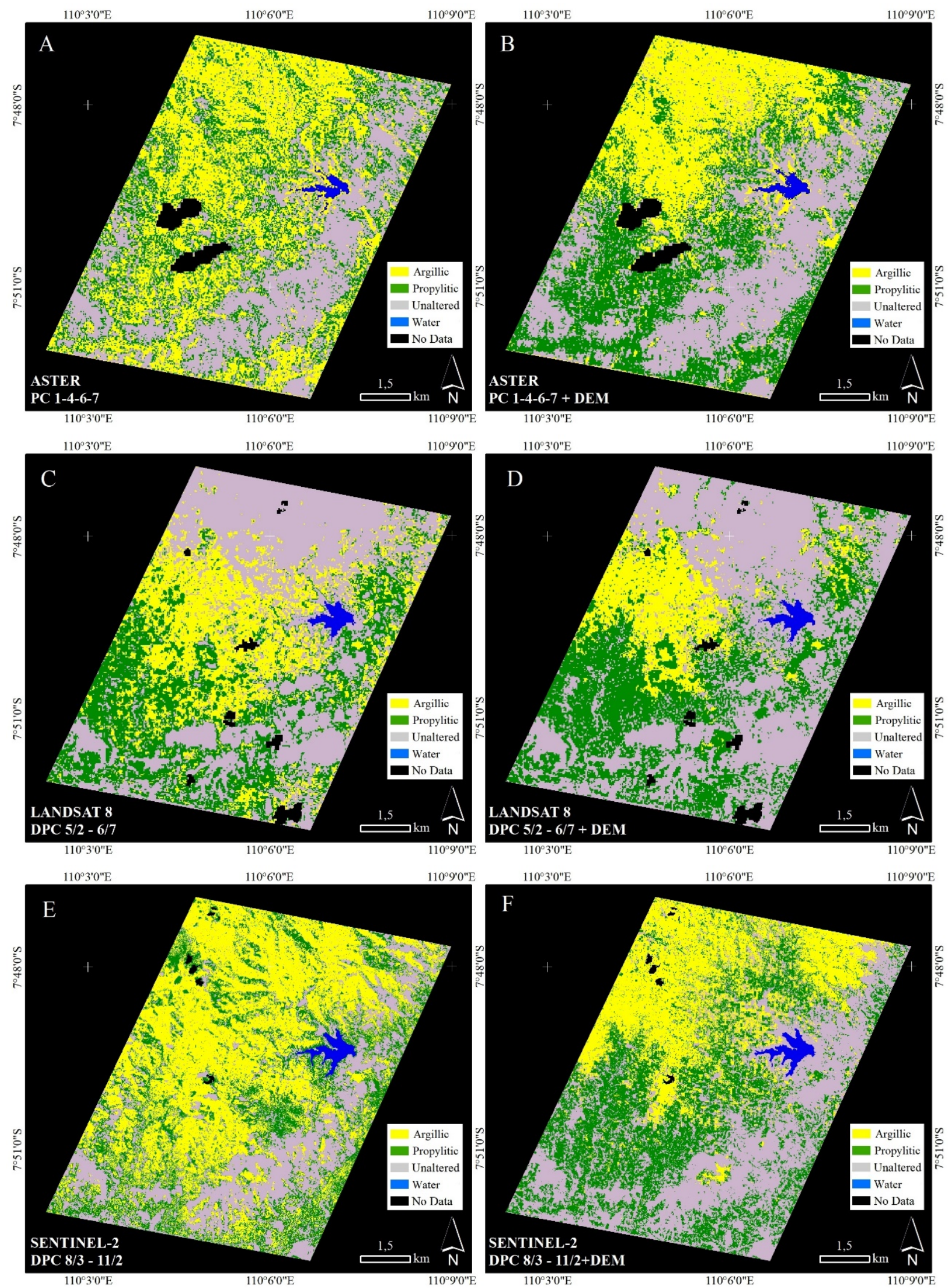

FIGURE 4. Hydrothermal classification map from ASTER PC 1-4-6-7 before DEM (A) and after DEM (B), Landsat 8 DPC image ratios of 5:2 and 6:7 before DEM (C) and after DEM (D), and Sentinel-2 DPC image ratios of 8:3 and 11:2 before DEM (E) and after DEM (F). 
TABLE 7. Eigenvector loadings for Landsat 8 PCA combination.

\begin{tabular}{|c|c|c|c|c|c|}
\hline & PC1 & PC2 & PC3 & PC4 & Alteration minerals \\
\hline Band 3 & 0.29 & 0.84 & 0.46 & - & \multirow{4}{*}{ Kaolinite + montmorillonite } \\
\hline Band 6 & 0.95 & -0.22 & -0.20 & - & \\
\hline Band 7 & 0.06 & -0.50 & 0.86 & - & \\
\hline Eigen values (\%) & $99.00 \%$ & $1.00 \%$ & $0.00 \%$ & - & \\
\hline Band 3 & 0.59 & 0.57 & 0.58 & - & \multirow{4}{*}{ Illite } \\
\hline Band 5 & 0.19 & -0.79 & 0.58 & - & \\
\hline Band 7 & 0.79 & 0.23 & -0.57 & - & \\
\hline Eigen values (\%) & $94.00 \%$ & $5.00 \%$ & $1.00 \%$ & - & \\
\hline Band 2 & 0.50 & 0.48 & 0.51 & 0.51 & \multirow{5}{*}{ Clay alteration } \\
\hline Band 5 & 0.52 & -0.8 & -0.03 & 0.29 & \\
\hline Band 6 & 0.70 & 0.27 & -0.38 & -0.54 & \\
\hline Band 7 & -0.04 & 0.23 & -0.77 & 0.60 & \\
\hline Eigen values (\%) & $93.00 \%$ & $5.00 \%$ & $2.00 \%$ & $0.00 \%$ & \\
\hline Band 2 & 0.50 & 0.51 & 0.48 & 0.51 & \multirow{5}{*}{ Limonitic alteration } \\
\hline Band 4 & 0.47 & 0.39 & -0.78 & -0.11 & \\
\hline Band 5 & 0.56 & -0.17 & 0.36 & -0.72 & \\
\hline Band 6 & 0.46 & -0.75 & -0.16 & 0.45 & \\
\hline Eigen values (\%) & $93.00 \%$ & $5.00 \%$ & $1.00 \%$ & $0.00 \%$ & \\
\hline
\end{tabular}

TABLE 8. Eigenvector loadings for Landsat 8 DPC combination.

\begin{tabular}{llcl}
\hline & DPC1 & DPC2 & $\begin{array}{l}\text { Alteration } \\
\text { minerals }\end{array}$ \\
\hline Band 3 : Band 4 & -0.423 & $\mathbf{- 0 . 9 0 6}$ & \\
Band 7 : Band 2 & -0.906 & $\mathbf{0 . 4 2 3}$ & Quartz \\
Eigen values (\%) & $97.00 \%$ & $\mathbf{3 . 0 0 \%}$ & \\
\hline Band 3 : Band 4 & -0.227 & $\mathbf{- 0 . 9 7 4}$ & Montmo- \\
Band 6 : Band 2 & -0.974 & $\mathbf{0 . 2 2 7}$ & rillonite \\
Eigen values (\%) & $99.20 \%$ & $\mathbf{0 . 8 0 \%}$ & \\
\hline Band 5 : Band 3 & -0.899 & $\mathbf{- 0 . 4 3 7}$ & \\
Band 7 : Band 2 & -0.437 & $\mathbf{0 . 8 9 9}$ & Illite \\
Eigen values (\%) & $97.70 \%$ & $\mathbf{2 . 3 0 \%}$ & \\
\hline Band 5 : Band 3 & -0.704 & $\mathbf{- 0 . 7 1}$ & \\
Band 6 : Band 2 & -0.71 & $\mathbf{0 . 7 0 4}$ & Chlorite \\
Eigen values (\%) & $98.40 \%$ & $\mathbf{1 . 6 0 \%}$ & \\
\hline Band 5 : Band 2 & -0.978 & $\mathbf{- 0 . 2 0 7}$ & \\
Band 6 : Band 7 & -0.207 & $\mathbf{0 . 9 7 8}$ & Epidote \\
Eigen values (\%) & $99.10 \%$ & $\mathbf{0 . 9 0 \%}$ & \\
\hline
\end{tabular}

fied hydrothermal alteration zone derived from Sentinel-2 DPC 8:3 and 11:2 before DEM and after DEM is shown in Figure 4E-F.

\section{Discussion}

In this research, the results of hydrothermal alteration mapping with PCA and DPC were at a moderate level. According to Figure 4, the combination of DEM with multispectral images was succeeded in decreasing the argillic zones and increasing propylitic and unaltered zones in all classification images. The increasing value of overall accuracy and KHAT statistic calculated from the multispectral classification result is proven by the increasing value of overall accuracy, exclusive and inclusive of DEM. However, the misclassification between argillic and propylitic zones is the main issue that delivers moderate agreement between two hydrothermal alteration maps. Three factors become critical that limit the generation of an acceptable classification of hydrothermal alteration: vegetation cover, number of training and testing samples, and spatial and spectral resolution of the multispectral images.

Vegetation cover will obstruct the penetration of satellite sensors to the ground and lead to the low hydrothermal alteration accuracy mapping. The distribution of field observations in the study area and the number of training and testing samples support the results obtained from remote sensing techniques for hydrothermal alteration mapping. Danoedoro (2015) studied the relationship between a number and sample distribution used for the multispectral classification with overall accuracy. The minimum sample required for multispectral classification with 15 classes or less is $8 \mathrm{n}$, where $\mathrm{n}$ is the class number. Since only four classes 
TABLE 9. Eigenvector loadings for Sentinel-2 PCA combination.

\begin{tabular}{|c|c|c|c|c|c|}
\hline & PC1 & PC2 & PC3 & PC4 & Alteration Minerals \\
\hline Band 3 & 0.26 & 0.86 & 0.45 & - & \multirow{4}{*}{ Kaolinite and montmorillonite } \\
\hline Band 11 & 0.00 & -0.47 & 0.89 & - & \\
\hline Band 12 & 0.97 & -0.23 & -0.12 & - & \\
\hline Eigen values (\%) & 98.76 & 0.65 & 0.59 & - & \\
\hline Band 3 & 0.18 & 0.94 & 0.28 & - & \multirow{4}{*}{ Illite } \\
\hline Band 8 & 0.33 & -0.33 & 0.89 & - & \\
\hline Band 12 & 0.93 & -0.06 & -0.37 & - & \\
\hline Eigen values (\%) & 96.08 & 3.71 & 0.21 & - & \\
\hline Band 2 & 0.14 & 0.81 & 0.52 & 0.26 & \multirow{5}{*}{ Clay alteration } \\
\hline Band 8 & 0.13 & -0.58 & 0.62 & 0.51 & \\
\hline Band 11 & -0.89 & -0.01 & 0.38 & -0.26 & \\
\hline Band 12 & -0.42 & 0.11 & -0.45 & 0.78 & \\
\hline Eigen values (\%) & 94.26 & 5.49 & 0.19 & 0.06 & \\
\hline Band 2 & 0.14 & 0.19 & 0.82 & 0.52 & \multirow{5}{*}{ Limonitic alteration } \\
\hline Band 4 & 0.16 & 0.36 & -0.57 & 0.72 & \\
\hline Band 8 & -0.52 & -0.72 & -0.03 & 0.45 & \\
\hline Band 11 & 0.82 & -0.56 & -0.05 & 0.06 & \\
\hline Eigen values (\%) & 94.82 & 4.70 & 0.45 & 0.03 & \\
\hline
\end{tabular}

TABLE 10. Eigenvector loadings for Sentinel-2 DPC combination.

\begin{tabular}{lrrl}
\hline & DPC1 & DPC2 & $\begin{array}{l}\text { Alteration } \\
\text { Minerals }\end{array}$ \\
\hline Band 3 : Band 4 & -0.39 & $\mathbf{- 0 . 9 2}$ & \\
Band 12 : Band 2 & -0.92 & $\mathbf{0 . 3 9}$ & Quartz \\
Eigen values (\%) & 96.99 & $\mathbf{3 . 0 1}$ & \\
\hline Band 3 : Band 4 & -0.21 & $\mathbf{- 0 . 9 8}$ & Montmo- \\
Band 11 : Band 2 & -0.98 & $\mathbf{0 . 2 1}$ & rillonite \\
Eigen values (\%) & 99.43 & $\mathbf{0 . 5 7}$ & \\
\hline Band 8 : Band 3 & -0.27 & $\mathbf{- 0 . 9 6}$ & \\
Band 12: Band 2 & -0.96 & $\mathbf{0 . 2 7}$ & Illite \\
Eigen values (\%) & 0.97 & $\mathbf{0 . 0 3}$ & \\
\hline Band 8 : Band 3 & -0.54 & $\mathbf{- 0 . 8 4}$ & \\
Band 11 : Band 2 & -0.84 & $\mathbf{0 . 5 4}$ & Chlorite \\
Eigen values (\%) & 96.10 & $\mathbf{3 . 9 0}$ & \\
\hline Band 8 : Band 2 & -0.95 & $\mathbf{- 0 . 3 0}$ & \\
Band 11 : Band 12 & -0.30 & $\mathbf{0 . 9 5}$ & Epidote \\
Eigen values (\%) & 99.32 & $\mathbf{0 . 6 8}$ & \\
\hline
\end{tabular}

of hydrothermal alteration classification were used, the minimum sample used should be 32 $(8 n=8 \times 4)$. This research met the requirement because it used 133 samples divided into 65 classification samples and 68 testing samples. However, more training and testing used for classification will lead to more accurate hydrothermal alteration mapping. Another factor that becomes a very critical aspect is the spatial and spectral resolution of multispectral data. ASTER has the best spectral resolution for the SWIR band to detect minerals reflectance consisting of six bands, while Sentinel-2 has the best spatial resolution in the SWIR region. However, in this research, the best hydrothermal alteration mapping accuracy was given by the Landsat- 8 image. This condition happens because of the selection of input combinations used for the PC process. This research compares the same wavelength combination in three different multispectral images so that the advantages of ASTER SWIR bands did not optimize properly.

From the spatial resolution aspect, Sentinel-2 failed to map the hydrothermal alteration because of inadequate training and test sample used for multispectral classification. The more detail and high spatial resolution of the multispectral images will lead to the more complex and various objects (mixed objects) found in a single training or testing area. In addition, the last factor that is also important in finding mineral prospects using remote sensing is the knowledge of interpreters about the study area. Knowing the location of hydrothermal alteration and its associated minerals in the field will give more information to compare the classification result with the actual condition. 
TABLE 11. Accuracy assessment of Landsat 8 multispectral classification.

\begin{tabular}{|c|c|c|c|c|c|c|c|c|}
\hline \multirow{2}{*}{ Images } & \multirow{2}{*}{ Band combination } & \multicolumn{3}{|c|}{ Before DEM } & \multicolumn{3}{|c|}{ After DEM } & \multirow{2}{*}{$\begin{array}{c}\text { Pairwise } \\
\text { test }\end{array}$} \\
\hline & & Accuracy (\%) & Kappa & $Z$ & Accuracy (\%) & Kappa & $\mathrm{Z}$ & \\
\hline \multirow{10}{*}{ 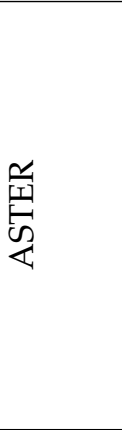 } & PCA 1-4-6-7 & 50.28 & 0.26 & 13.24 & 54.45 & 0.32 & 16.47 & 2.25 \\
\hline & PCA 1-3-5-6 & 45.78 & 0.2 & 10.41 & 51.32 & 0.28 & 14.46 & 2.89 \\
\hline & PCA 1-3-4-7 & 44.49 & 0.19 & 9.63 & 50.44 & 0.27 & 13.9 & 3.06 \\
\hline & PCA 1-3-4-5 & 45.05 & 0.19 & 9.98 & 49.64 & 0.26 & 13.21 & 2.33 \\
\hline & $\mathrm{DPC}$ b1/b2-b6/b2 & 44.57 & 0.19 & 9.75 & 49.08 & 0.25 & 12.7 & 2.18 \\
\hline & $\mathrm{DPC}$ b3/b1-b6/b1 & 45.78 & 0.2 & 10.17 & 49.96 & 0.26 & 13.17 & 3.01 \\
\hline & $\mathrm{DPC} b 3 / \mathrm{b} 1-\mathrm{b} 4 / \mathrm{b} 1$ & 43.86 & 0.17 & 9.0 & 47.55 & 0.22 & 11.37 & 2.16 \\
\hline & DPC b3/b1-b4/b6 & 46.58 & 0.22 & 11.23 & 49.00 & 0.25 & 12.7 & 1.76 \\
\hline & $\mathrm{DPC}$ b3/b2-b4/b6 & 45.94 & 0.21 & 10.81 & 50.36 & 0.27 & 13.52 & 1.11 \\
\hline & $\mathrm{DPC}$ b2/b1-b3/b1 & 42.89 & 0.16 & 8.54 & 48.11 & 0.23 & 11.84 & 2.25 \\
\hline \multirow{10}{*}{ 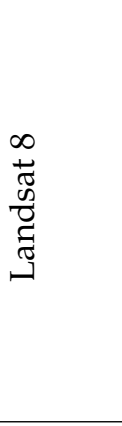 } & PCA 3-5-7 & 51.57 & 0.28 & 13.86 & 54.37 & 0.32 & 16.11 & 1.54 \\
\hline & PCA 3-6-7 & 51.41 & 0.28 & 13.83 & 55.09 & 0.33 & 16.68 & 1.98 \\
\hline & PCA 2-5-6-7 & 54.55 & 0.32 & 16.39 & 57.58 & 0.37 & 18.7 & 1.62 \\
\hline & PCA 2-4-5-6 & 52.61 & 0.29 & 14.88 & 57.34 & 0.37 & 18.49 & 2.52 \\
\hline & $\mathrm{DPC}$ b3/b4-b7/b2 & 54.63 & 0.33 & 16.5 & 57.10 & 0.36 & 18.53 & 1.37 \\
\hline & $\mathrm{DPC}$ b5/b3-b7/b2 & 56.15 & 0.35 & 17.73 & 58.94 & 0.39 & 19.92 & 1.51 \\
\hline & $\mathrm{DPC}$ b5/b3-b6/b2 & 54.87 & 0.33 & 16.62 & 58.22 & 0.38 & 19.35 & 1.85 \\
\hline & DPC b5/b2-b6/b7 & 56.64 & 0.36 & 17.93 & 59.50 & 0.4 & 20.35 & 1.61 \\
\hline & DPC b5/b4-b6/b7 & 53.10 & 0.3 & 15.33 & 53.97 & 0.32 & 16.11 & 1.5 \\
\hline & $\mathrm{DPC}$ b4/b2-b5/b4 & 55.67 & 0.34 & 17.21 & 58.62 & 0.39 & 19.72 & 1.67 \\
\hline \multirow{10}{*}{ 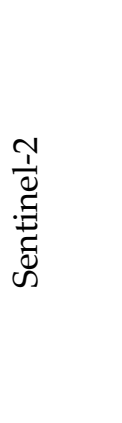 } & PCA 3-11-12 & 45.53 & 0.18 & 23.05 & 46.17 & 0.2 & 25.15 & 1.32 \\
\hline & PCA 3-8-12 & 44.50 & 0.17 & 21.05 & 46.38 & 0.2 & 25.34 & 2.89 \\
\hline & PCA 2-8-11-12 & 46.44 & 0.2 & 24.65 & 46.79 & 0.21 & 25.86 & 0.75 \\
\hline & PCA 2-4-8-11 & 46.89 & 0.2 & 25.22 & 48.65 & 0.23 & 29.02 & 2.58 \\
\hline & $\mathrm{DPC}$ b3/b4-b12/b2 & 40.33 & 0.11 & 13.98 & 43.14 & 0.16 & 16.32 & 3.69 \\
\hline & $\mathrm{DPC}$ b8/b3-b12/b2 & 44.55 & 0.17 & 21.89 & 46.32 & 0.2 & 21.08 & 2.35 \\
\hline & DPC b8/b3-b11/b2 & 46.61 & 0.21 & 26.72 & 49.37 & 0.25 & 32.04 & 3.74 \\
\hline & DPC b8/b2-b11/b12 & 44.98 & 0.19 & 24.74 & 47.16 & 0.22 & 23.34 & 2.44 \\
\hline & DPC b8/b4-b11/b12 & 44.21 & 0.18 & 23.8 & 46.87 & 0.22 & 23.08 & 2.89 \\
\hline & $\mathrm{DPC}$ b4/b2-b8/b4 & 44.79 & 0.18 & 22.56 & 46.89 & 0.21 & 22.12 & 2.73 \\
\hline
\end{tabular}




\section{CONCLUSION}

In this work, ASTER, Landsat 8, and Sentinel2 were evaluated in hydrothermal alteration mapping. Analysis of multispectral images, ASTER, Landsat 8, and Sentinel-2 provide promising findings. $\mathrm{PC}$ technique is a fast and straightforward method to detect the abundance of alteration minerals in the study area. In the area of heavily vegetated terranes, DPC works better than PCA in mapping mineral images. This provides information that band ratios can reduce the vegetation effect in dense vegetation. From the comparison, it can be concluded that in this research, Landsat 8 works better than ASTER and Sentinel-2 in the hydrothermal alteration mapping. The combination of Landsat 8 images ratio of 5:2 and 6:7 succeed in mapping the hydrothermal alteration with an accuracy of $56.64 \%$ and a kappa coefficient of 0.36. The DEM data were used and applied to all multispectral images and succeed in increasing the overall accuracy. However, despite the multispectral classification result is moderate level, this study provides information about hydrothermal alteration mapping accuracy that can be achieved using multispectral images. This method needs to be improved to increase accuracy, especially by developing a new method that can highlight minerals in the dense vegetation, i.e., vegetation suppression.

\section{ACKNOWLEDGEMENTS}

The author(s) would like to thank the Department of Geological Engineering, Gadjah Mada University, for their partly research funding, granted to the second author and fellow academic colleagues for material assistance and guidance that provided for completing this work.

\section{REFERENCES}

Abrams, M.J., Ashley, R.P., Rowan, L.C., Goetz, A.F.H. and Kahle, A.B. (1977) Mapping of hydrothermal alteration in the Cuprite mining district, Nevada, using aircraft scanner images for spectral region 0.46-2.36 mm. Geology, vol. 5, pp. 713-718.

Carranza, E.J.M. (2002) Geologically-constrained Mineral Potential Mapping, Ph.D. Thesis, Delft University of Technology, The Netherlands, 480p.

Carranza, E.J.M. and Hale, M. (2002) Mineral imaging with Landsat Thematic Mapper data for hy- drothermal alteration mapping in heavily vegetated terrane, International Journal of Remote Sensing, 23, 4827-4852.

Cohen, J. (1960) A coefficient of agreement for nominal scales. Education and Psychological Measurement, vol. 20, pp. 37-45.

Congalton, R.G. and Green, K. (1999) Assessing the Accuracy of Remotely Sensed Data: Principles and Practices. Lewis Publishers, Boca Raton, FL, $137 \mathrm{pp}$.

Crosta, A.P., Souza Filho, C.R., Azevedo, F. and Brodie, C. (2003) Targeting key alteration minerals in epithermal deposits in Patagonia, Argentina, Using ASTER imagery and principal component analysis, International Journal of Remote sensing, 24, PP. 4233-4240.

Danoedoro, P. (2015) Pengaruh jumlah dan metode pengambilan titik sampel penguji terhadap tingkat akurasi klasifikasi citra digital penginderaan jauh, Prosiding Simposium Nasional Sains Geoinformasi ke-4. Fakultas Geografi, Universitas Gadjah Mada, Yogyakarta.

Ferrier G, White K, Griffiths G, Bryant R, Stefouli M. (2001) The mapping of hydrothermal alteration zones on the island of Lesvos, Greece using an integrated remote sensing dataset. International Journal of Remote Sensing, ISSN 0143-1161.

Fraser, S.J. and Green, A.A. (1987) A software defoliant for geological analysis of band ratios, International Journal of Remote Sensing, vol. 8, no. 3, pp. 525-532.

Gasmi, A., Gomez, C., Zouari, H., Masse, A., Ducrot, D. (2016) PCA and SVM as geo-computational methods for geological mapping in the southern of Tunisia, using ASTER remote sensing data set. Arabian Journal of Geoscience, vol 9:753 .

Harjanto, A. (2008) Magmatisme dan mineralisasi di daerah Kulon Progo dan sekitarnya Jawa Tengah. Disertasi Doktor. Institut Teknologi Bandung. Bandung.

Lehmann, E.L. and Casella, G. (1998) Theory of Point Estimation, 2nd Edition, New York: Springer.

Pramumijoyo, P. (2017) Geologi, geokimia, dan karakteristik fluida hidrotermal pada endapan epithermal sulfidasi rendah di daerah Sangon, Kokap, DIY. Tesis. Teknik Geologi, Universitas Gadjah Mada. Yogyakarta (unpublished).

Rahardjo, W., Sukandarrumidi, and Rosidi, H.M.D. (1995) Peta Geologi Lembar Yogyakarta, Jawa, Pusat Penelitian dan Pengembangan Geologi, Bandung.

Rowan, L. C., Schmidt, R. G. and Mars, J. C. (2006) Distribution of hydrothermally altered rocks in the Reko Diq, Pakistan mineralized area based on spectral analysis of ASTER data. Remote Sens. Environ., 104, 74-87. 
Sulthoni, J.N. (2017) Geologi dan kontrol struktur terhadap mineralisasi epithermal berdasarkan analisis tensor dan geokimia di Gunung Ijo dan sekitarnya, Pegunungan Kulonprogo, DIY. Skripsi. Teknik Geologi, Universitas Jenderal Soedirman. Purwokerto (unpublished).

Tangestani, M. H., and Moore, F. (2002) Porphyry copper alteration mapping at the Meiduk area, Iran. International Journal of Remote Sensing, 23, 4815-4826.

Taranik, J.V., and Crósta, A.P. (1996) Remote sensing for geological and mineral resources, an assessment of tools for geoscientists in the future. International Archives of Photogrammetry and Remote Sensing, vol. 31, B7, pp. 689-698.

Vermote, E.F., El Saleous, N.Z., Justice, C.O. (2002) Atmospheric Correction of MODIS data in Visible to Middle infrared: First Result, Remote Sensing of Environment, Vol. 83 (97 - 111).

Wicaksono, P. and Danoedoro, P. (2012) Multitemporal Vegetation Cover Mapping using ALOS AVNIR-2: The Important of Atmospheric Effect Normalization on Multitemporal Analysis. Report and Proceedings of ALOS Application and Verification Project in Indonesia. Jakarta: JAXA and LAPAN.

Widagdo, A., Pramumijoyo, S., Harijoko, A., Setiawan, A., 2016, Kajian Pendahuluan Kontrol Struktur Geologi Terhadap Sebaran BatuanBatuan di Daerah Pegunungan KulonprogoYogyakarta, Proceeding, Seminar Nasional Kebumian ke-9, 6-7 Oktober, Yogyakarta, pp. 9-20. 